\title{
Trees on farmlands in the western central part of Senegal: implications for a carbon project
}

\author{
Fatimata NIANG-DIOP ${ }^{1 *}$, Steen N. CHRISTENSEN ${ }^{1,3}$, Anders S. BARFOD ${ }^{2}$, \\ Bienvenu SAMBOU ${ }^{1}$, Mamadou DIOP ${ }^{1}$, Assane GOUDIABY ${ }^{1}$, Elie A. PADONOU ${ }^{4,5}$ and \\ Anne Mette LYKKE ${ }^{3}$ \\ ${ }^{l}$ Institute of Environmental Sciences, University of Cheikh Anta Diop, Dakar, Senegal. \\ ${ }^{2}$ Department of Biology, Faculty of Science, Aarhus University, Denmark. \\ ${ }^{3}$ Department of Bioscience, Faculty of Technical Sciences, Aarhus University, Denmark. \\ ${ }^{4}$ School of Tropical Forestry, National University of Agriculture, Kétou, Benin. \\ ${ }^{5}$ Laboratory of Applied Ecology, Faculty of Agronomic Sciences, University of Abomey-Calavi, Cotonou, \\ Benin. \\ "Corresponding author ; E-mail: faniangdiop@live.fr ; fatimata7.niang@ucad.edu.sn
}

\begin{abstract}
Trees are rapidly disappearing from agrarian landscapes in many tropical countries, a severe problem to rural populations, who depend on wood and non-timber forest products (NTFP) for their livelihoods. The aim of this study was to determine tree density, diversity, biomass and carbon stock in farmlands in Senegal and to gain insight in the socio-economic determinants of the tree cover. An allometric model was developed to estimate the average above ground biomass (AGB) based on field investigations of 235.5 ha of agricultural fields. In total, 25 tree species were recorded with an average density of 1.6 tree $\mathrm{ha}^{-1}$ and a canopy cover of $1 \%$. The AGB was $8.9 \mathrm{t}$. ha $\mathrm{ha}^{-1}$ corresponding to $4.45 \mathrm{t} \mathrm{C} \mathrm{ha}^{-1}$. A single species, Cordyla pinnata, accounted for $50 \%$ of all the trees censured. Investigations of google Earth images showed considerable change in tree density during the investigated periods $\left(2004,2009\right.$ and 2013). The tree density decreased at the rate of $3 \%$ per year ${ }^{-1}$ from $2004-$ 2009 and $6.4 \%$ per year ${ }^{-1}$ from $2009-2013$. Based on these results, all the trees would be lost in 30 years from 2009 and in 16 years from 2013 if this trend continues. Informants were generally interested in increasing the number of fruit trees. On average, they were willing to allocate $19 \%$ of their land for planting of new trees. Tree planting, however, has not been traditionally considered an option by the landowners, since livestock damage on young trees was too big and fencing not an option, but the recent years tree planting with certification for carbon sale has been initiated with support from outside.

(C) 2020 International Formulae Group. All rights reserved.
\end{abstract}

Keywords: Africa, forest resources, deforestation, local management, woody biomass.

\section{INTRODUCTION}

Trees on agricultural lands and the nonforest environment including parklands are in some cases more valuable to poor as well as more well-off rural households than forest trees
(Pouliot et al., 2012). Local people protect trees in the fields for many reasons. Trees provide direct ecosystem services (food, firewood, timber, fencing material, medicine, improved soil fertility and enhancement of local climate 
conditions) while also contributing to global climate change mitigation (Lykke et al., 2004; Mbow et al., 2014). Management of trees in agricultural systems is an important option for better carbon sequestration and removal of $\mathrm{CO}_{2}$ from the atmosphere. Trees on agrosystems can increase carbon sequestration and smallholder farmers can benefit from the REDD+ mechanism. Carbon incentive was able to increase carbon sequestered on farms and agrosystems offers an opportunity for sequestering a large amount of $\mathrm{C}$ (Thangata and Hildebrand, 2012; Fujisaki et al., 2017).

Many tree species in farmland play an important role (Diedhiou et al., 2014; Diatta et al., 2016a), especially in the season when food stocks are low (Lykke et al., 2004). An exemple is Cordyla pinnata, one of the most preferred species in Senegal, particularly in the Saloum region (Diop et al., 2011) which provides 20 ecosystem services to local people (Dieng et al., 2016).

The large-scale transformation of natural vegetation into agroecosystems has detrimental effects on plant diversity and composition (Botha et al., 2017). In West Africa where the dependence on trees is high, this biodiversity loss is of particular concern. On one side, tree decline often has severe longterm consequences for the livelihood of the poorest farmers, on the other side, poverty is widely recognized as a leading factor in the degradation of the environment (Elasha et al., 2006; Chikanda, 2009). Soil degradation is another negative consequence of tree decline that constitutes a constant threat to food security in West Africa (Tieszen, 2004).

In Senegal, $32.8 \%$ of the population live in severe poverty (UNDP, 2019). In the densely populated Saloum region in West-Central Senegal, where this study was conducted, forests and savannas have largely been replaced by farmlands with sparsely distributed trees. Woomer et al. (2004) estimated the loss of above-ground carbon in the Saloum region to be more than twice as big as the national average.

Detailed field-based mapping of woody vegetation is pivotal for gaining insight in the spatial and temporal dynamics of plant resources. Applying remote sensing techniques to vegetation is challenging due to sparse cover, high background soil signal, and difficulty to differentiate between spectral signals of bare soil and dry vegetation (Tsalyuk et al., 2017).

Likewise, the perceptions of rural dwellers on how they use the environment and observe changes are an important short-cut to understanding the role of human impact on the woody vegetation (Adesina and Chianu, 2002; Lykke et al., 2004). This knowledge is a prerequisite for developing management plans for tree planting and for sustainable tree harvesting practices based on local preferences.

This study aims to document the distribution of trees, their density, diversity, biomass and carbon stock in farmlands in the Saloum region of Senegal, and to estimate rates of tree decline by comparing present and former tree density based on field data and information derived from Google Earth. Finally, we aim to gain insight into the socioeconomic determinants for tree utilization based on local knowledge and thereby make recommendations for natural resource management practices.

\section{MATERIALS AND METHODS \\ Study site}

The study was conducted in farmlands adjacent to four villages (Table 1) along the perimeter of Patako Forest Reserve in the Saloum region of Senegal (Figure 1). This is situated in the so-called 'Peanut Basin', which has been under cultivation for a century, and since the 1990s with little use of fallow or other soil conservation practices (Tappan et al., 2004).

The altitude within the study area ranges between 10 and $40 \mathrm{~m}$ above sea level. The average rainfall is $700 \mathrm{~mm}$ with large annual variations. The annual precipitation declined by $20 \%$ compared to the period before the 1970s (Tappan et al., 2000; Woomer et al., 2004). During the period 1961-1987, the duration of the rainy season decreased by 0.46 
days year $^{-1}$ (Anyadike, 1993). Lixisols are common throughout the study area and although the soil type is potentially fertile (CRKSD, 2002), it turned increasingly sandy and nutrient-poor due to leaching caused by intensive farming without fallow periods. This led to a decrease in agricultural fields that were arable without fertilization. The average population density within the study area was 148 inhabitants per $\mathrm{km}^{2}$ in 2013 (ANSD, 2013).

The main activities in the area are agriculture, the most important food-crop in the study area is pearl millet (Pennisetum glaucum) and the main commercial crop is groundnut (Arachis hypogea) (Diop et al., 2011). All crops are rain-fed and cultivated using a mixture of animal drawn plows and handheld tillage tools. In the dry season, vegetables are grown in riverine areas, especially onion (Allium cepa). The most important planted fruit trees are cashew (Anacardium occidentale) and mango (Mangifera indica). The cash income of most households relied heavily on one or more family members living and working outside the village. Many tried to supplement their earnings by setting up small shops, but usually these contributed only little to the household economy.

\section{Field investigations}

Fifteen sampling plots were established of 15.7 ha each: four were placed outside each of three villages (Keur Lahine Sokhna, Ndiayène Momath Thiane and Keur Saloum Diane) and three plots were placed around the fourth village (Keur Boubacar Mane). Two of the plots were placed $400-600 \mathrm{~m}$ from the village centre in the NE and SW quadrants; two plots were situated $800-916 \mathrm{~m}$ from the village centre in the NW and SE quadrants (Figure 2). First, the geographical coordinates of the centre of the village were marked as a waypoint on the handheld GPS navigator. Next, the investigator walked along the radius in a given compass direction, until the inner circle demarcating the plot was reached. From this radius all trees between the inner and outer circle segment delimiting the plot were recorded until the investigator reached the radius perpendicular to that of the starting point.

Trees with a diameter at breast height $(\mathrm{dbh}) \geq 5 \mathrm{~cm}$ were recorded and identified to species level. Tree height and canopy cover were estimated. The locations were georeferenced using a handheld GPS navigator. Photographs of individual trees were filed in a database (Figure 3).

\section{Interviews}

The planning of and selection of candidates for the semi-structured interviews were discussed with community leaders during preliminary visits to the villages. Adult female and male members of different households were interviewed individually in the local Wolof language. After a short introduction describing the background of the study, we asked a number of structured questions, divided into four categories; (i) social conditions (ii) economic activities (size of land, yields and income from crops), (iii) purpose of cutting trees and (iv) tree planting possibilities (constraints, soil enhancing species, desired species, land for trees). In several cases, the questioning continued as a non-structured interview on related subjects.

\section{Data analysis}

All statistical tests were performed using General Linear Models (GLM). Based on visual inspection of the residual plot, data were log-transformed when necessary to meet the assumptions on normality and homogeneity of variance. Each plot was critically evaluated for deviating large numbers of trees and the density of any given species was adjusted for if the plot included (i) livestock paths, (ii) trees planted for demarcation of fields or (iii) large numbers of the exotic species, Azadirachta indica growing in the shade of larger trees. Trees planted to mark field boundaries were omitted from the analysis, as were the numerous A. indica saplings often recorded under big trees because of bird dispersal.

Above ground biomass (AGB) was calculated from dbh using the allometric 
equation for tropical trees developed by Brown (1997): $\mathrm{AGB}=42.69-12.800 \mathrm{D}+1.242 \mathrm{D}^{2}$, where $\mathrm{AGB}$ is measured in $\mathrm{kg}$ and $\mathrm{D}=\mathrm{dbh}$ in $\mathrm{cm}$.

To estimate canopy cover, the canopy diameter was measured on photos of the individual trees.

Google Earth images (dated 21 Feb. 2004, 23 April 2009 and 10 March 2013) were used to estimate changes in tree density and to evaluate spatial tree distribution patterns. On these images, it was possible to identify individual canopies. The trees were counted and their canopy cover estimated.

Best fit equations were used to estimate the relationship between canopy cover estimated from Google Earth images and dbh. On this basis, dbh and following AGB can be estimated directly from Earth images by combining the best fit equation with the allometric equation: $\mathrm{AGB}=$ $42.69-12.800 \cdot e^{(0.76+0.845 \cdot \ln (C))}+1.242 \cdot e^{(1.52+1.69 \cdot \ln (C))}$ The equation is particularly useful in areas with good Google Earth or orthophoto coverage and a similar distribution of trees. The total carbon mass was calculated as $50 \%$ of the AGB.

The average value of farmland crops was estimated from the informants' crop yields and income from sale of crops. The following exchange rate was used: $100 \mathrm{CFA}=0.15$ Euro.

Table 1: The four villages considered in the study from theSaloum region in western Senegal.

\begin{tabular}{|c|c|c|c|c|}
\hline Villages & $\begin{array}{l}\text { Keur Boubacar } \\
\text { Mane }\end{array}$ & Saloum & $\begin{array}{ll}\text { Keur } & \text { Lahine } \\
\text { Sokhna } & \\
\end{array}$ & $\begin{array}{l}\text { Ndiayene } \\
\text { Momath Thiane }\end{array}$ \\
\hline $\begin{array}{l}\text { Geographical } \\
\text { coordinates }\end{array}$ & $\begin{array}{l}13^{\circ} 37^{\prime} 54 " \mathrm{~N} \\
16^{\circ} 16^{\prime} 25^{\prime \prime} \mathrm{W}\end{array}$ & $\begin{array}{l}13^{\circ} 45^{\prime} 16^{\prime \prime N} \\
16^{\circ} 16^{\prime} 3^{\prime \prime} \mathrm{W}\end{array}$ & $\begin{array}{l}13^{\circ} 43^{\prime} 41^{\prime \prime N} \\
16^{\circ} 13^{\prime} 16^{\prime \prime} \mathrm{W}\end{array}$ & $\begin{array}{l}13^{\circ} 43^{\prime} 39^{\prime \prime} \mathrm{N} \\
16^{\circ} 17^{\prime} 55^{\prime \prime} \mathrm{W}\end{array}$ \\
\hline Inhabitants (2013) & $555^{\mathrm{a}}$ & 1368 & 770 & 501 \\
\hline $\begin{array}{l}\text { Distance from Patako } \\
\text { Forest }(\mathrm{km})\end{array}$ & 2.0 & 4.2 & 1.0 & 3.1 \\
\hline
\end{tabular}

${ }^{a}$ including inhabitants of the neighbouring village - Keur Momath Souna.
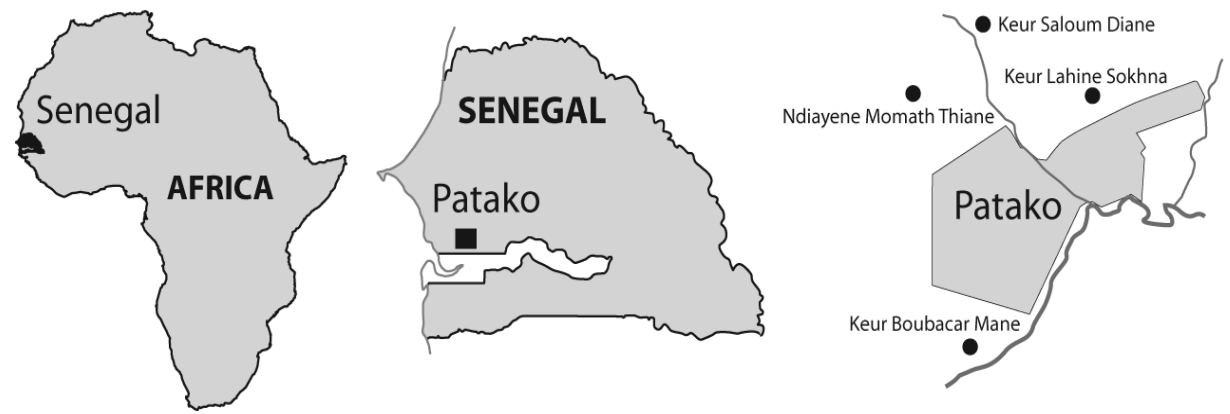

Figure 1: Study sites in farmlands adjacent to Patako Forest Reserve, Senegal. 


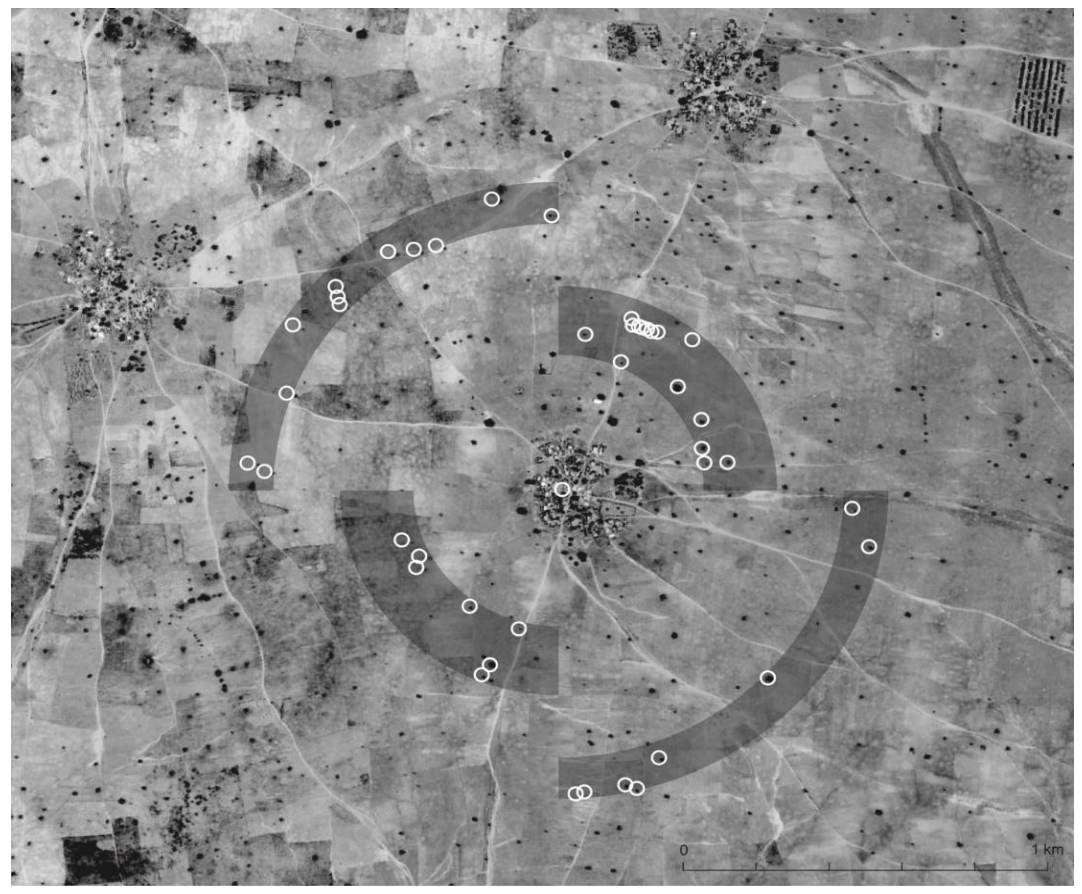

Figure 2: Plots for tree recording around one of the four studied villages, Ndiayene Momath Thiane. Each of the recorded trees is indicated with white circles.

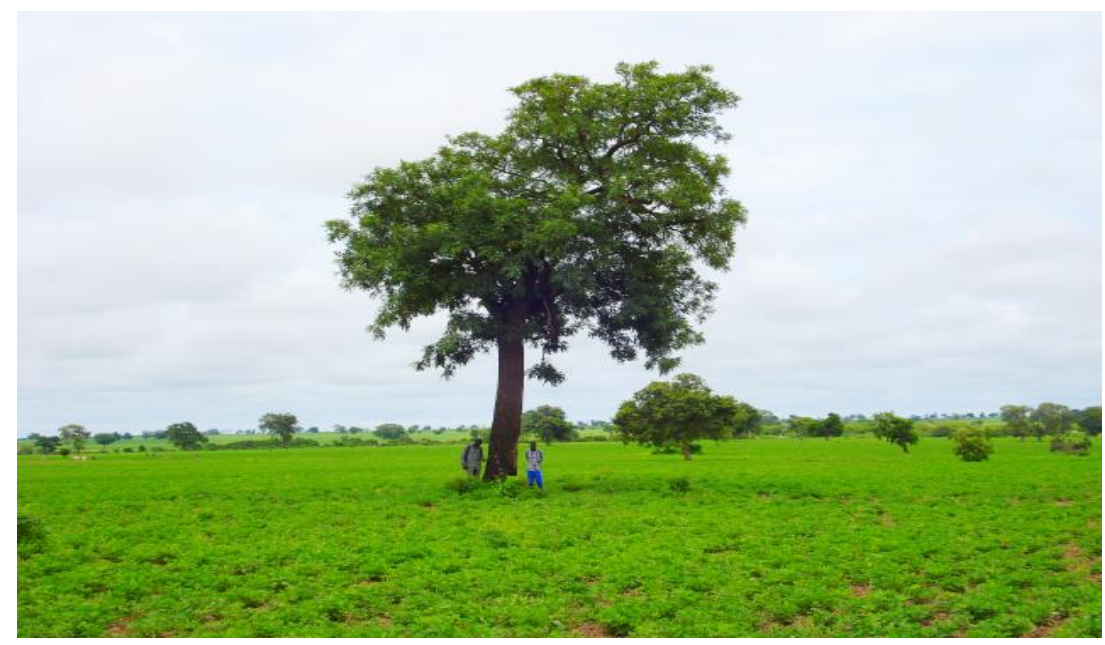

Figure 3: Cordyla pinnata near Keur Saloum Diane village and a view of the adjacent farmlands with very few trees.

\section{RESULTS}

Density, above ground biomass and carbon

The average tree density on the 235.5 ha surveyed was 1.6 trees $\mathrm{ha}^{-1}$, with a range among plots from 0.4 to 4.0 trees $\mathrm{ha}^{-1}$. The average AGB was estimated to $8.9 \mathrm{tha}^{-1}$, varying from
2 to $25 \mathrm{tha}^{-1}$ over the plots. This corresponds to an average of $4.45 \mathrm{t} \mathrm{C} \mathrm{ha}^{-1}$. The average tree height was $11 \mathrm{~m}$, ranging from 2.0 to $22.5 \mathrm{~m}$. The average dbh was $62 \mathrm{~cm}$, ranging from 5 to $256 \mathrm{~cm}$. Based on measurements of tree canopies on the photos, the average canopy 
cover in the surveyed area was quantified to $1 \%$. In the village Keur Saloum Diane, a significantly higher density of trees, both for the directly recorded tree density $(p<0.05)$ and for the adjusted density $(p<0.01)$ was recorded. The AGB was also significantly higher in this village $(p<0.05)$.

The results of the best fit equations between canopy cover and dbh for the five most common tree species and for all measurable trees are presented in Table 2. Of the 202 trees recorded in the area, 50\% were identified to Cordyla pinnata ( 0.80 trees $\left.^{-1} \mathrm{a}^{-1}\right)$, $26 \%$ to Azadirachta indica $\left(0.40\right.$ trees $\left.^{-1} \mathrm{ha}^{-1}\right)$ and $5 \%$ to Ficus glumosa $\left(0.08\right.$ trees ha $\left.^{-1}\right)$. In total 25 woody species were recorded (Figure 4 ).

\section{Change in tree density and spatial distribution patterns}

Comparisons between trees identified on Google Earth images and trees recorded on ground made it possible to estimate the magnitude of change in tree density and tree spatial distribution patterns (Table 3). During the five-year period from 2004 to $2009,14 \%$ of the trees had disappeared varying from 5 to $45 \%$ between the plots. A total of $3 \%$ of the trees were lost per year. With this rate of change all the trees in the study area would be lost in 30 years. The reduction rate of the tree cover from 2004 to 2009 corresponds to an estimated carbon loss of $143 \mathrm{~kg} \mathrm{C} \mathrm{ha}^{-1}$ year $^{-1}$.

With Google Earth images from 2009 to $2013,26 \%$ of the trees had disappeared varying from 8 to $44 \%$ between the plots. A total of $6.4 \%$ of the trees were lost per year. With the current change rate, all the trees would be lost in 16 years. The change rate from 2009 to 2013 corresponds to an estimated carbon loss of 220 $\mathrm{kg} \mathrm{C} \mathrm{ha}^{-1}$ year $^{-1}$.

\section{Purpose of cutting trees}

The local inhabitants were questioned about their motives for tree cutting. 'Need for firewood' was mentioned by $72 \%$ of the informants as the most important incentive for tree cutting, followed by 'need for timber' mentioned by $32 \%$ and 'need for fencing material' mentioned by $25 \%$. A few informants cited the other use of local timber for making mortars, charcoal and furniture. According to the interviews, the average value of crops grown on farmland was 63 Euro ha $^{-1}$ year $^{-1}$. Among the informants there was an average of 13 ha of cropland per household.

Several of the informants pointed out that decreasing duration of the rainy season and declining soil fertility were most concerns regarding the consequences of the on-going deterioration of their natural surroundings. A few linked the decreasing number of trees to the perceived decrease in precipitation as well as duration of the rainy season. Most of the informants cited chemical fertilizers as the main solution to the problem of declining in soil fertility.

\section{Tree planting possibilities}

The informants mentioned a number of constraints in relation to tree planting (Figure 5). 'No fencing' and 'tree seed expenses' were the major constraints for tree planting. This was followed by 'problems of termite attacks' and 'lack of energy/time'. The $14 \%$ of the informants, who cited 'lack of energy/time' as a constraint, had an average age that was 14 years older than the overall average.

Plants with beneficial effects on the soil, such as nitrogen enrichment, form an integrated part of many agroforestry systems. However, only $36 \%$ of the informants were aware of such properties in plants. Four species were cited by more than two informants as being beneficial for the soil: Faidherbia albida (6), Cordyla pinnata (5), Guiera senegalensis (3) and Parkia biglobosa (3).

The informants unanimously wanted more useful fruit trees in the area. On average, they were willing to allocate $19 \%$ ( 2 ha) of their land to cultivation of their preferred trees, a figure that ranged from 0.1 to 10.0 ha among informants. Most informants wished to grow trees inside the fields (92\%), and fewer preferred planting in hedgerows (17\%) or trees in home gardens $(17 \%)$. For trees planted in fields, a total of $94 \%$ of the informants preferred trees planted in rows, and only $6 \%$ wanted trees planted in a scattered manner corresponding to actual spatial distribution of trees. 


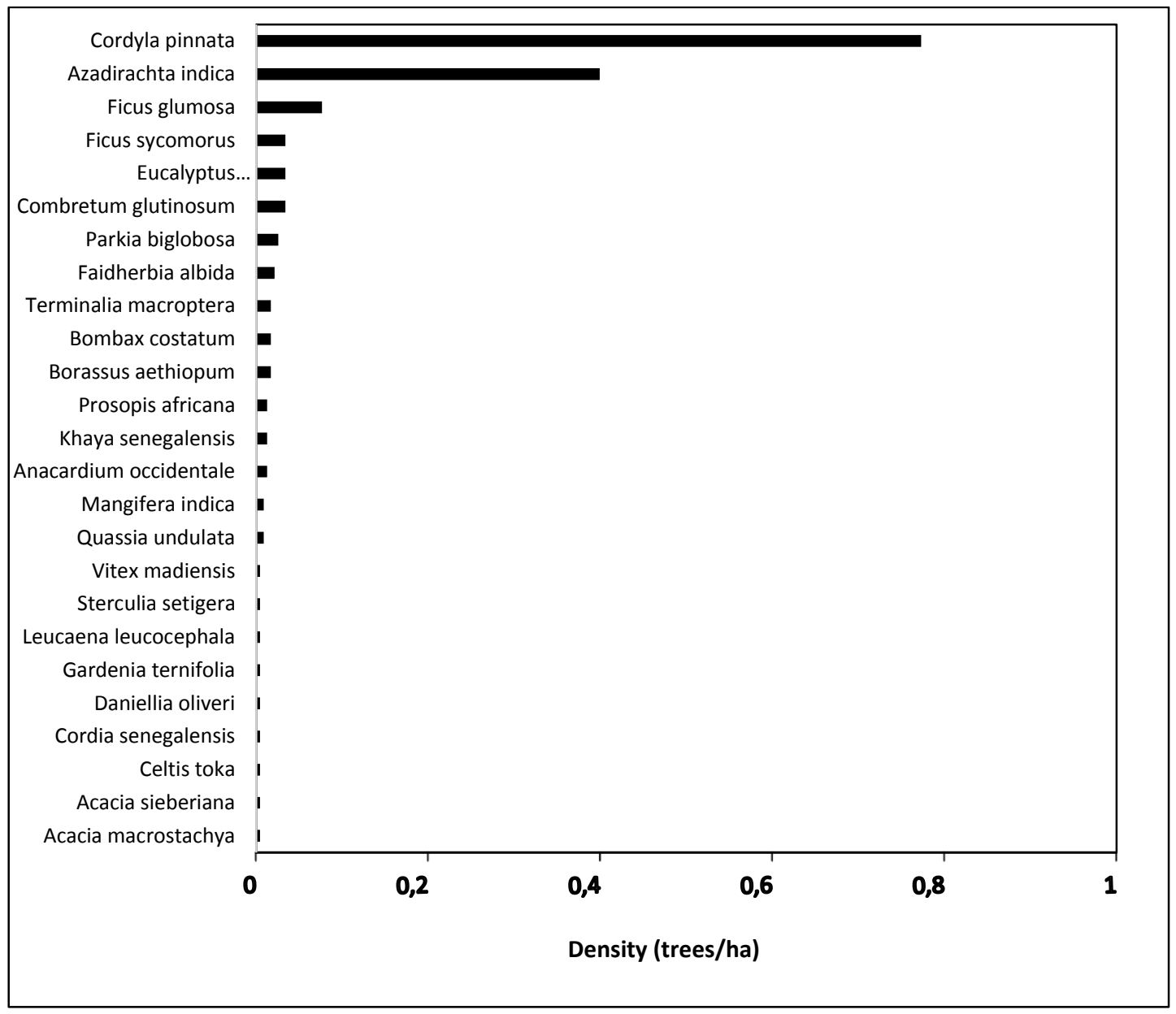

Figure 4: Total number of each tree species recorded in 15 study plots, 235.5 ha in total.

Table 2: Best fit equations for correlations between canopy cover (C) estimated from Google Earth and dbh.

\begin{tabular}{|c|c|c|c|c|c|}
\hline Tree species & $\mathbf{n}$ & $\begin{array}{l}\text { Average } \\
\text { canopy } \\
\text { cover } \\
\left(\mathbf{m}^{2}\right)\end{array}$ & $\begin{array}{l}\text { Average } \\
\text { dbh }(\mathrm{cm})\end{array}$ & Best fit equation & $P$-value \\
\hline Cordyla pinnata & 125 & 63 & 67 & $\mathrm{DBH}=32.7+0.55 \cdot \mathrm{C}$ & $<0.0001$ \\
\hline Azadirachta indica & 24 & 29 & 36 & $\mathrm{DBH}=\exp \{9.7+0.90 \cdot \ln (\mathrm{C})\}$ & $<0.0001$ \\
\hline Ficus glumosa & 14 & 91 & 160 & $\mathrm{DBH}=53.2+1.18 \cdot \mathrm{C}$ & $<0.001$ \\
\hline Parkia biglobosa & 5 & 102 & 95 & $\mathrm{DBH}=26.6+0.67 \cdot \mathrm{C}$ & $<0.05$ \\
\hline Faidherbia albida & 4 & 30 & 25 & $\mathrm{DBH}=7.2+0.59 \cdot \mathrm{C}$ & $<0.05$ \\
\hline All measured trees & 202 & 61 & 71 & $\begin{array}{l}\mathrm{DBH} \quad=\quad \exp \{0.76+ \\
0.845 \cdot \ln (\mathrm{C})\}\end{array}$ & $<0.0001$ \\
\hline
\end{tabular}


Table 3: Estimated number of trees for each plot and village in 2004, 2009 and 2013.

\begin{tabular}{llccc}
\hline Plot & Village & $\begin{array}{c}\text { Number of tree } \\
\text { in 2004 }\end{array}$ & $\begin{array}{c}\text { Number of } \\
\text { tree in 2009 }\end{array}$ & Number of tree in 2013 \\
\hline 1 & Keur Boubacar Mane & 16 & 13 & 8 \\
2 & Keur Boubacar Mane & 40 & 36 & 20 \\
3 & Keur Boubacar Mane & 27 & 15 & 12 \\
4 & Keur Saloum Diane & 39 & 35 & 30 \\
5 & Keur Saloum Diane & 54 & 49 & 35 \\
6 & Keur Saloum Diane & 66 & 63 & 40 \\
7 & Keur Saloum Diane & 30 & 28 & 21 \\
8 & Keur Lahine Sokhna & 16 & 13 & 12 \\
9 & Keur Lahine Sokhna & 31 & 29 & 24 \\
10 & Keur Lahine Sokhna & 28 & 24 & 22 \\
11 & Keur Lahine Sokhna & 22 & 12 & 11 \\
12 & Ndiayene Momath Thiane & 21 & 19 & 9 \\
13 & Ndiayene Momath Thiane & 16 & 14 & 6 \\
14 & Ndiayene Momath Thiane & 10 & 7 & 7 \\
15 & Ndiayene Momath Thiane & 11 & 9 & \\
\hline
\end{tabular}

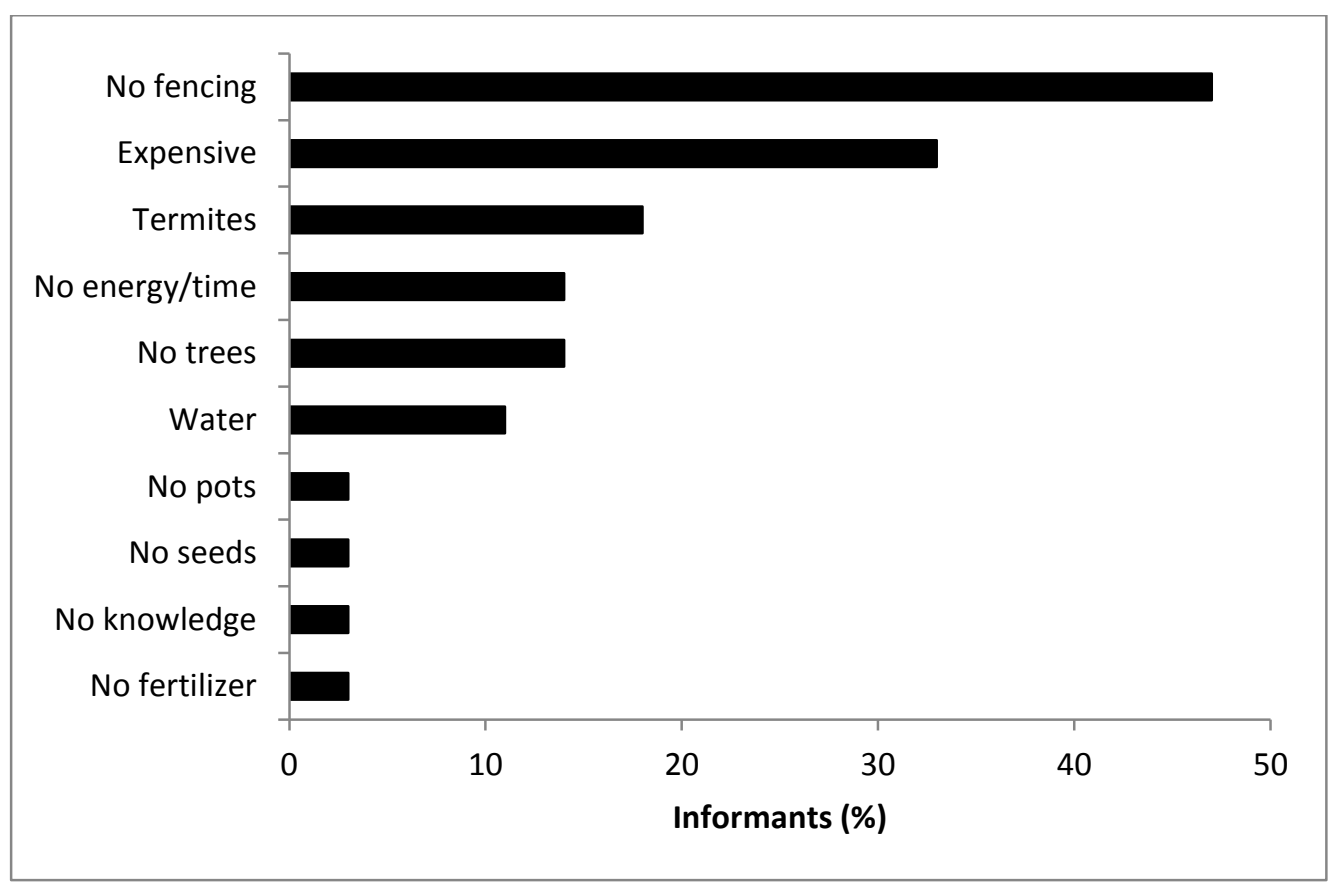

Figure 5: Constraints related to tree planting experienced by informants. 


\section{DISCUSSION}

\section{Density, above ground biomass and carbon}

The tree density and diversity recorded in this study were low and in decline due to intensive peanut farming and a high population density. The first cultivation of peanut date back to around 1900. It intensified dramatically in the 1950s and 1960s, and by the 1990s peanut farms had expanded to a point where only a few patches of protected woodlands were left (Tappan al., 2004). The region is one of the earliest intensively cultivated regions in Senegal and with its long history of dense human settlements it has become showcase for unsustainable rural development.

A total of 25 tree species were recorded; $75 \%$ of the individuals belonged to just two species: Cordyla pinnata and Azadirachta indica, the latter being an exotic species. In the same area, a total of 35 species with a tree density less than four individual per hectare was found by Diatta et al. (2016b).

The overall density of 1.6 trees ha ${ }^{-1}$ was very low. The $1 \%$ canopy cover estimated in this study is distinctly lower than the $8 \%$ canopy cover recorded for the region overall (Woomer et al., 2004) in 1994. An average biomass of $8.9 \mathrm{tha}^{-1}$ was also low compared to a study in Segou, which is situated in a much drier region. In the Malian traditional parkland agroforestry systems, the biomass varied between 45 and $108 \mathrm{t} \mathrm{C}^{-1}$ (Takimoto et al., 2008). The satellite based global biomass carbon map produced by Ruesch and Gibbs in 2008 estimates a potential $400 \mathrm{t}$ carbon in the study area and an actual 4-5 $\mathrm{t} \mathrm{C} \mathrm{ha-} \mathrm{in}$ farmland, which correspond well to the actual carbon stock in the present study area (4.45 t C $\left.h^{-1}\right)$.

Trees decline in agricultural lands is a global phenomenon (Goodal et al., 2014). The relative importance of decreasing precipitation and anthropogenic impact as determinants of deforestation is of key importance for future attempts to manage plant resources in an environmentally sustainable way. In more densely populated areas, where smallholders depend on trees for firewood and constructions, the forest is mainly declining for anthropogenic reasons (Tappan et al., 2000). This was clearly demonstrated by Diatta (2013) in the same area where local communities have pointed out the negative impact of agriculture, wood exploitation and rainfall decline. Tree decline is noted, in the adjacent forest, the protected Patako Forest (Sambou et al., 2007), where the average tree density ranged between 190 and 361 trees $\mathrm{ha}^{-1}$, which is 100 times more than the corresponding figures recorded in farmlands. In the Sahelo-Sudanian zone in northwestern Senegal, Gonzalez (2001) recorded a decline in tree density (trees of height $\geq 3 \mathrm{~m}$ ) from 10 trees ha $^{-1}$ in 1954 to 7.8 trees ha ${ }^{-1}$ in 1989, which corresponds to a yearly deforestation rate of 0.06 trees ha $^{-1}$. This is similar to the decline rate of 0.05 trees $\mathrm{ha}^{-1}$ year $^{-1}$ tree recorded in the present study. However, since the tree density in our study area was five times smaller, we can conclude that the human pressure on the tree resources is much higher in relative terms.

Although in many cases, it is difficult to find a relation between satellite-based variables and widespread measures of vegetation quality, such as diversity and density (Lykke et al., 2007), high resolution in Google Earth makes it possible to estimate tree density. The decline rate from 2004 to 2009 and 2009 to 2013 corresponds to a carbon loss of $143 \mathrm{~kg} \mathrm{ha}^{-1}$ year $^{-1}$ and $220 \mathrm{~kg} \mathrm{ha}^{-1}$ year $^{-1}$, respectively, which is considerably less than the estimated average carbon loss of $924 \mathrm{~kg} \mathrm{ha}^{-1}$ year $^{-1}$ for the New Peanut Basin ecoregion in Senegal (Woomer et al., 2004). The biomass recorded in this study was already low because of largescale deforestation in the past by commercial loggers and local communities, which means that there is little available biomass to loose. In the 1970s, many trees were removed from the fields because they were considered a hindrance for tilling, and some informants reported that smallholders in 1982-83, were rewarded with food from the Senegalese Ministry of Agriculture, if they cleared two hectares of land completely for trees including regrowth. In the fields, we observed that tree saplings were weeded away. Juvenile plants 
were heavily browsed by livestock inside fields and villages. Azadirachta indica was the only exception being found in all age-classes outside the fields. The high resilience of this species is due to its reshooting ability, vigorous growth, limited browser palatability and effective seed dispersal by birds.

We discussed with the informants whether a more environmentally sustainable management of the livestock could possibly prevent the negative effect of uncontrolled browsing. Unclear land tenure and lack of sanctions for damages inflicted on tree crops by livestock make it impossible to protect newly established plantations. The informants considered fencing the only effective way to prevent damages inflicted by browsing, basically since it is the only solution, they were aware of. To purchase the expensive fencing materials, however, farmers depend on support from the outside. In nearby Fathala Forest, Niang-Diop et al. (2011) recorded a $90 \%$ mortality rate among the naturally regenerated tree seedlings of Cordyla pinnata mainly due to browsing. Termites also often constitute a constraining factor on reforestation, since insecticides are too costly for most smallholders.

\section{Cordyla pinnata - a key species}

Despite the fact that $C$. pinnata was the most abundant tree in our study with $50 \%$ of all trees, the informants considered it in decline. It is a popular tree on farmland, because it delivers edible fruits, firewood and timber, but it is also in risk of overexploitation (Lykke 2000). It is one of the most appreciated tree species in this region (Diop et al., 2011). In this area, it provides 20 ecosystem services to local people (Dieng et al., 2016). In farmland not far from the study area, $C$. pinnata comprised $60 \%$ of all trees and the density amounted to 4 trees ha $^{-1}$ (Samba 2001; Samba et al., 2001). In the Patako Forest, $C$. pinnata ranked the fourth most abundant tree, with a density of 9 trees ha $^{-1}$ (Sambou 2004). In the Fathala Forest, $C$. pinnata constituted only $1.5 \%$ of the 1837 trees monitored, and the overall density amounted to 2.7 trees $\mathrm{ha}^{-1}$ (Lykke 1998).

\section{Soil enhancing plants}

Managing agricultural lands for increased soil carbon sequestration enhances agronomic and ecosystem sustainability through associated increases in soil nutrient cycling and aggregate stability (Fultz et al., 2013). In this study, one third of the informants interviewed recognized the beneficial effects of plants on soil fertility. This is lower than a study from Nigeria, where $82 \%$ of informants cited improvement of soil fertility as the major reason for adopting alley cropping systems (Adesina and Chianu, 2002). In our study, the well-known nitrogen fixing species, Faidherbia albida, was most frequently mentioned as a plant with a positive effect on soil fertility. Guiera senegalensis was mentioned by three informants as improving soil properties for cultivation. A study conducted in Senegal confirmed that Guiera senegalensis enhances the levels of inorganic nitrogen in the soil and increases the carbon mineralization (Dossa et al., 2009). In the same area, Samba et al. (2012) have also mentioned the positive effect of Cordyla pinnata on soil fertility and crop productivity.

\section{Useful tree species}

The role of trees and agroforestry in reducing smallholder's exposure to climaterelated risks are well known (Mbow et al., 2014; Lasco et al., 2014). In Africa, trees on agricultural lands generate multiple provisioning ecosystem services. Medicinal uses, contribution to fodder for livestock and importance for human nutrition (Sinare and Gordon, 2014; Mbow et al., 2014). In rural areas, resource management is often a trade-off between the ecosystem services provided by trees and income generation from cultivated crops (Lykke et al., 2009).

In an uncertain future with climate change and extreme weather events, these domesticated and semi-domesticated trees on farmland will undoubtedly play an important 
role in delivering food security and famine food, for example during extended periods of drought.

\section{Conclusion}

The Patako region is one of the most intensively cultivated regions in Senegal outside the capital region and it is heavily impacted by a steadily increasing human population. Conversion of dry forest into farmlands leads to depletion of the natural resource base, a negative development that is further reinforced by the fact that the surviving useful trees in fields can no longer be exploited on a sustainable basis. The decision to cultivate useful trees on farmland is a trade-off between the perceived value of the products and services delivered by the trees on one hand and the nutritional and monetary value from the crops that can be grown on the same land on the other (opportunity costs). There is an interest for planting trees in the local communities, but traditionally there are several constraints. Our results reveal that few trees will remain in the study area in close furure, if current practices are not changed. There is a great need to increase tree planting in the study area like in several other areas of West Africa. Planting of useful trees can provide an income to the villagers. Alternative sources of income are needed during the unproductive juvenile stages, which may last up to 10 years. Although the informants of the present study expressed willingness to increase the number of trees on their land, they also mentioned how difficult it was to procure appropriate conditions for tree planting. The biggest bottleneck was lack of money to pay for fencing materials, irrigation systems and pesticides for termite control. An economic input to the area is therefore needed to make tree planting an attractive possibility for local farmers. Selling carbon credits can be a lucrative way to assure such an income during the establishment period. A project aiming at generating climate, livelihood and ecosystem benefits to local farmers is presently being established and certified via the Plan Vivo mechanism. The opportunity costs of the ecosystem services will be covered by carbon credits to local people. Hopefully this will prove an efficient mean to change the vicious circle of decline in tree populations leading to increased poverty and even higher pressures on the natural resources.

\section{COMPETING INTERESTS}

The authors state that they have no competing interests.

\section{AUTHORS' CONTRIBUTIONS}

Protocol design and implementation are made by SNC with the contribution and supervision of AML, ASB, FND, MD, BS and AG. A first version was written by $\mathrm{SNC}$ and this version of the manuscript is updated by FND with the contribution of AML, ASB, MD and EAP.

\section{ACKNOWLEDGEMENTS}

We are grateful to SUN (EU-Inco-dev 031685) and Undesert (EU-FP7 243906) and to the villagers in the Patako area.

\section{REFERENCES}

Adesina AA, Chianu J. 2002. Determinants of farmers' adoption and adaptation of alley farming technology in Nigeria. Agroforestry Systems 55: 99-112. DOI: 10.1023/A:1020556132073

Anyadike RN. 1993. Patterns and variations of rainfall over Banjul, Gambia. Singapore Journal of Tropical Geography, 14: 1-14. DOI: $10.1111 / \mathrm{j} .1467$ 9493.1994.tb00220.x

Brown S. 1997. Estimating biomass and biomass change in tropical forests - A primer. FAO Forestry Paper, 134: 1-55. http://www.fao.org/3/w4095e/w4095e00 .htm\#Contents. Accessed 24.05.2020.

Chikanda A. 2009. Environmental Degradation in Sub-Saharan Africa. In Environment and Health in Sub-Saharan Africa: Managing an Emerging Crisis. Springer: Dordrecht, 79-94. DOI: 10.1007/978-14020-9382-1. 
Diatta AA, Ndour N, Manga A, Sambou B, Faye CS, Diatta L, Goudiaby A, Mbow C, Dieng SD. 2016a. Services ecosystémiques du parc agroforestier à Cordyla pinnata (Lepr. ex A. Rich.) Milne-Redh. dans le Sud du Bassin Arachidier (Sénégal). Int. J. Biol. Chem. Sci., 10(6): 2511-2525. DOI: 10.4314/ijbcs.v10i6.9

Diatta AA, Ndour N, Manga A, Sambou B, Faye CS, Diatta L, Mbow C. 2016 b. Composition floristique et dynamique du parc agroforestier à Cordyla pinnata (Lepr. ex A. Rich.) Milne-Redh. dans le Sud du Bassin Arachidier (Sénégal). Int. J. Biol. Chem. Sci., 10(4): 1805-1822. DOI: 10.4314/ijbcs.v10i4.29

Dieng SD, Diop M, Goudiaby A, Niang-Diop F, Faye LC, Guiro I, Sambou S, Lykke AM, Sambou B. 2016. Caractérisation des services écosystémiques fournis par Cordyla pinnata dans la périphérie de la Forêt classée de Patako au Sénégal. VertigO, 16(2): 1-17. URI: iderudit/1038192ar.

Diedhiou MAA, Faye E, Ngom D, Touré MA. 2014. Identification et caractérisation floristiques des parcs agroforestiers du terroir insulaire de Mar Fafaco, Sénégal. Journal of Applied Biosciences, 79: 6855-6866. DOI: 10.4314/jab.v79i1.11

Diop M, Sambou B, Goudiaby A, Guiro I, Niang-Diop F. 2011. Ressources végétales et préférences sociales en milieu rural sénégalais. Bois et Forêts des Tropiques, 310: 57-68. DOI: 10.19182/bft2011.310.a20459

Dossa EL, Khouma M, Diedhiou I, Sene M, Kizito F, Badiane AN, Samba SAN, Dick RP. 2009. Carbon, nitrogen and phosphorus mineralization potential of semiarid Sahelian soils amended with native shrub residues. Geoderma, 148: 251-260.

DOI:

10.1016/j.geoderma.2008.10.009

Elasha BO, Medany M, Niang-Diop I, Nyong T, Tabo R, Vogel C. 2006. Background paper on Impacts, vulnerability and adaptation to climate change in Africa. African workshop on adaptation implementation of decision 1/CP.10 of the UNFCCC Convention, Accra, Ghana, http://www.preventionweb.net/english/pr ofessional/publications/v.php?id=8386.

Accessed 24.05.2020.

Fujisaki K, Chapuis-Lardy L, Albrecht A, Razafimbelo T, Chotte JL, Chevallier T. 2017. Data synthesis of carbon distribution in particle size fractions of tropical soils: Implications for soil carbon storage potential in croplands. Geoderma, 313: 41-51. DOI: 10.1016/j.geoderma.2017.10.010

Fultz LM, Moore-Kucera J, Zobeck TM, Acosta-MartÃnez V, Wester DB, Allen VG. 2013. Organic carbon dynamics and soil stability in five semiarid agroecosystems. Agriculture, Ecosystems \& Environment, 181: 231-240. DOI: 10.1016/j.agee.2013.10.004

Gonzalez P. 2001. Desertification and a shift of forest species in the West African Sahel. Climate Research, 17(2): 217-28. DOI: 10.3354/cr017217

Goodall KE, Bacon CM, Mendez VE. 2015. Shade tree diversity, carbon sequestration, and epiphyte presence in coffee agroecosystems: A decade of smallholder management in San Raman, Nicaragua. Agriculture, Ecosystems \& Environment, 199: 200-206. DOI: h10.1016/j.agee.2014.09.002

Lasco RD, Delfino RJP, Catacutan DC, Simelton ES, Wilson DM. 2014. Climate risk adaptation by smallholder farmers: the roles of trees and agroforestry. Current Opinion in Environmental Sustainability, 6: 83-88. DOI: 10.1016/j.cosust.2013.11.013

Lykke AM. 1998. Assessment of species composition change in savanna vegetation by means of woody plants' size class distributions and local information. Biodiversity and Conservation, 7: 1261-1275. 
Lykke AM. 2000. Local perceptions of vegetation change and priorities for conservation of woody-savanna in Senegal. Journal of Environmental Management, 59: 107-120. DOI: 10.1006/jema.2000.0336

Lykke AM, Barfod AS, Svendsen CT, Greve M, Svenning J-C. 2009. Climate change mitigation by carbon stock forests - the case of semi-arid West Africa. Earth and Environmental Science, 8, IOP Publishing. $\quad$ DOI: 10.1021/acs.est.6b00122

Lykke AM, Kristensen MK, Ganaba S. 2004. Valuation of local use and dynamics of 56 woody species in the Sahel. Biodiversity and Conservation, 13:1961-1990. DOI: 10.1023/B:BIOC.0000035876.39587.1a

Lykke AM, Sambou B, Mbow C, Zuur AF, Ieno EN, Smith GM. 2007. Redundancy analysis and additive modelling applied on savanna tree data. In Analyzing Ecological data, Statistics for Biology and Health, Zuur AF, Leno EN and Smith GM (eds.). Springer: New York; 547-560. DOI: 10.1007/978-0-387-45972-1_31

Mbow C, Van Noordwijk M, Luedeling E, Neufeldt H, A Minang P, Kowero G. 2014. Agroforestry solutions to address food security and climate change challenges in Africa. Current Opinion in Environmental Sustainability, 6: 61-67. DOI: 10.1016/j.cosust.2013.10.014

Niang-Diop F, Lykke AM, Sambou B. 2011. Régénération naturelle de Cordyla pinnata dans une savane soumise au feu et au pâturage. Sécheresse, 22(3): 186191. DOI: $10.1684 / \mathrm{sec} .2011 .0315$

Pouliot M, Treue T, Obiri BD, Ouedraogo B. 2012. Deforestation and the Limited Contribution of Forests to Rural Livelihoods in West Africa: Evidence from Burkina Faso and Ghana. AMBIO, 41: 738-750. DOI: 10.1007/s13280-0120292-3

Ruesch A, Gibbs HK. 2008. New IPCC tier-1 Global Biomass Carbon Map for the year 2000. http://cdiac.ornl.gov/epubs/ndp/global_c arbon/carbon_documentation.html. Oak Ridge National Laboratory, Oak Ridge, Tennessee. Accessed 27.05.2020.

Samba SAN. 2001. Effet de la litière de Cordyla pinnata sur les cultures: approche expérimentale en agroforesterie. Annals of Forest Science, 58: 99-107. DOI: 10.1051/forest:2001110 Samba SAN, Camiré C, Margolis HA. 2001. Allometry and rainfall interception of Cordyla pinnata in a semi-arid agroforestry parkland, Senegal. Forest Ecology and Management, 154: 277-288. DOI: $10.1016 / \mathrm{S} 0378-1127(00) 00633-2$

Samba SAN, Faye E, Gueye T, Hank M, Camire C. 2012. Cordyla pinnata améliore les propriétés du sol et la productivité des cultures. Int. J. Biol. Chem. Sci., 6(2): 714-725. DOI: 10.4314/ijbcs.v6i2.15

Sambou B. 2004. Evaluation de l'état de la dynamique et des tendances évolutives de la flore et de la végétation ligneuses dans les domaines soudanien et sub-guinéen au Sénégal. Thèse de Doctorat d'Etat, Université Cheikh Anta Diop, Dakar. P. 241. DOI: $10.4314 /$ ijbcs.v10i6.9

Sambou B, Bâ AT, Goudiaby A, Sonko I, Mbow C. 2007. Étude de la flore et de la végétation ligneuse pour la détermination des types d'usages compatibles avec une gestion durable de la forêt classée de Patako (Sénégal). Webbia, 62(1): 85-96. DOI: $10.1080 / 00837792.2007 .10670818$

Sinare H, Gordon LJ. 2015. Ecosystem services from woody vegetation on agricultural lands in Sudano-Sahelian West Africa. Agriculture, Ecosystems \& Environment, 200: 186-199. DOI: 10.1016/j.agee.2014.11.009

Takimoto A, Nair PKR, Alavalapati JRR. 2008. Socioeconomic potential of carbon sequestration through agroforestry in the West African Sahel. Mitigation and Adaptation Strategies for Global Change, 13:745-761. DOI:10.1007/s11027-0079140-3 
Tappan GG, Hadj A, Wood EC, Lietzow RW. 2000. Use of Argon, Corona, and Landsat imagery to assess 30 years of land resource changes in west-central Senegal. Photogrammetric Engineering and Remote Sensing, 66(6): 727-735. DOI: 0099-1112/00/6606-727\$3.00

Tappan GG, Sall M, Wood EC, Cushing WM. 2004. Ecoregions and land cover trends in Senegal. Journal of Arid Environments, 59: 427-462.

DOI:

10.1016/j.jaridenv.2004.03.018

Thangata PH, Hildebrand PE. 2012. Carbon stock and sequestration potential of agroforestry systems in smallholder agroecosystems of sub-Saharan Africa: Mechanisms for reducing emissions from deforestation and forest degradation (REDD+). Agriculture, Ecosystems \& Environment, 158: 72-183. DOI: 10.1016/j.agee.2012.06.007.
Tsalyuk M, Kelly M, Getz WM. 2017. Improving the prediction of African savanna vegetation variables using time series of MODIS products. ISPRS Journal of Photogrammetry and Remote Sensing, 131: 77-91. DOI: 10.1016/j.isprsjprs.2017.07.012

UNDP. 2019. Human Development Report 2019. Beyond income, beyond averages, beyond today: Inequalities in human development in the 21 st century. New York.

http://hdr.undp.org/en/content/humandevelopment-report-2019.

Woomer PL, Tieszen LL, Tappan G, Touré A, Sall M. 2004. Land use change and terrestrial carbon stocks in Senegal. Journal of Arid Environments, 59(3): $625-42$.

DOI:

10.1016/j.jaridenv.2004.03.025. 